\title{
GIS-Based Study of Prioritized Gully Erosion and Flood Locations in Ebonyi State
}

\author{
Onuoha, D. C.*; Igu, Nwabueze I.** and Oluwole, Rotimi*** \\ *Department of Environmental Management, Nnamdi Azikiwe University Awka, P. M. B. 5025, Awka, Nigeria. \\ Tel: +2348037603720. E-mail:chidave2k3@yahoo.com \\ **Department of Geography and Meteorology, Nnamdi Azikiwe University Awka, P. M. B. 5025, Awka, \\ Nigeria. \\ ***National Geohazards Centre, Anambra State Office, Awka, Anambra State, Nigeria. \\ E-mail:wolerotimi@gmail.com.
}

\begin{abstract}
Gully erosion and flood is a major environmental disaster in south eastern part of Nigeria. This study adopts Geographic Information System (GIS) as a tool in the identification of flood and gully erosion locations in Ebonyi State. 31 flood and erosion locations were identified using GPS receiver and field ground investigation. Gully erosion and flood severity map was produced using the SRTM (Shuttle Radar Topographic Mission), which was imported into the ArcGIS platform. The result shows that gully erosion sites were well dispersed around Ajali Sandstone geological Formation. The slope characteristic was ascertained to be greater than $15^{\circ}$ which encourages flood and gully erosion activities. The flood and erosion severity map produced showed risk and vulnerability of settlements and infrastructure while the observation on site showed loss of properties, economic trees, biodiversity and obstructed access; thus endangered human existence. This study therefore recommended public enlightenment on their role in flood and erosion control, enlistment of geologists, environmental managers and other experts in flood and erosion control planning for better understanding of the terrain before adopting any measure of control. Also the production of gully and flood severity map for other areas within the southeastern Nigeria is necessary to enable better control of these environmental hazards.
\end{abstract}

Keywords: Gully Erosion, Flood Locations, GIS

DOI: $10.7176 / \mathrm{JEES} / 10-2-11$

Publication date: February 29th 2020

\subsection{Introduction}

Erosion is a natural geological process in which soils and bedrocks are detached and transported away by water, wind or glacier (Posen et al, 2011). In the Nigeria environment water is the main agent of erosion. The simplest form of erosion is as raindrop which involves detachment of soil particles. Sheet erosion occurs as uniform wear while rills and gullies are formed from concentrated flow.

Erosion is a worldwide phenomenon involving several geological processes tending to reduce land surface to equilibrium (Allen, 1997). It is the part of normal processes of denudation associated with climatic factors and hydrological cycles. Erosion processes are usually gravity driven and are related to second law of thermodynamics which states that there is always a tendency towards increase in entropy in any natural system. This implies that every natural system always strives to achieve a lower energy state and this induces breakdown (Angrist and Hepler, 1967). Gully development is a threshold phenomenon. It occurs only when a threshold in terms of flow hydraulics, rainfall, topography, pedology and land use has been exceeded (Possen et al., 2011).

Generally erosion has destructive impacts in all over Nigeria. It devastates the land and crops, destroys infrastructure such as roads and houses and has occasionally resulted in loss of lives.

\subsection{Aim and Objectives}

The aim of this study is to assess Ebonyi State with specific reference to only five (5) prioritized sites earmarked for detailed investigation to determine erosion and flood severity. To achieve this aim, the following objectives will be pursued: 
1. To derive a geo-database of the selected five gully erosion and flood sites in Ebonyi State,

2. to acquire spatial reference data to facilitate data integration and analysis

3. to identify areas prone to gully erosion and flooding; areas liable to gully erosion and flooding; and areas not vulnerable to gully erosion and flooding for the purposes of relocation and resettlement, and

4. to assess the socio-economic impacts of gully erosion and flood hazards on the people.

\subsection{Study area}

The study area lies within latitude $5^{\circ} 40^{1} 0^{11} \mathrm{~N}$ to $6^{\circ} 45^{1} 0^{11} \mathrm{~N}$ and longitude $7^{0} 35^{1} 0^{11} \mathrm{E}$ to $8^{\circ} 20^{1} 60^{11} \mathrm{E}$. It has a land mass of about 5,530 $\mathrm{km}^{2}$. Ebonyi state has 13 Local Government Areas as shown in Figure 1.

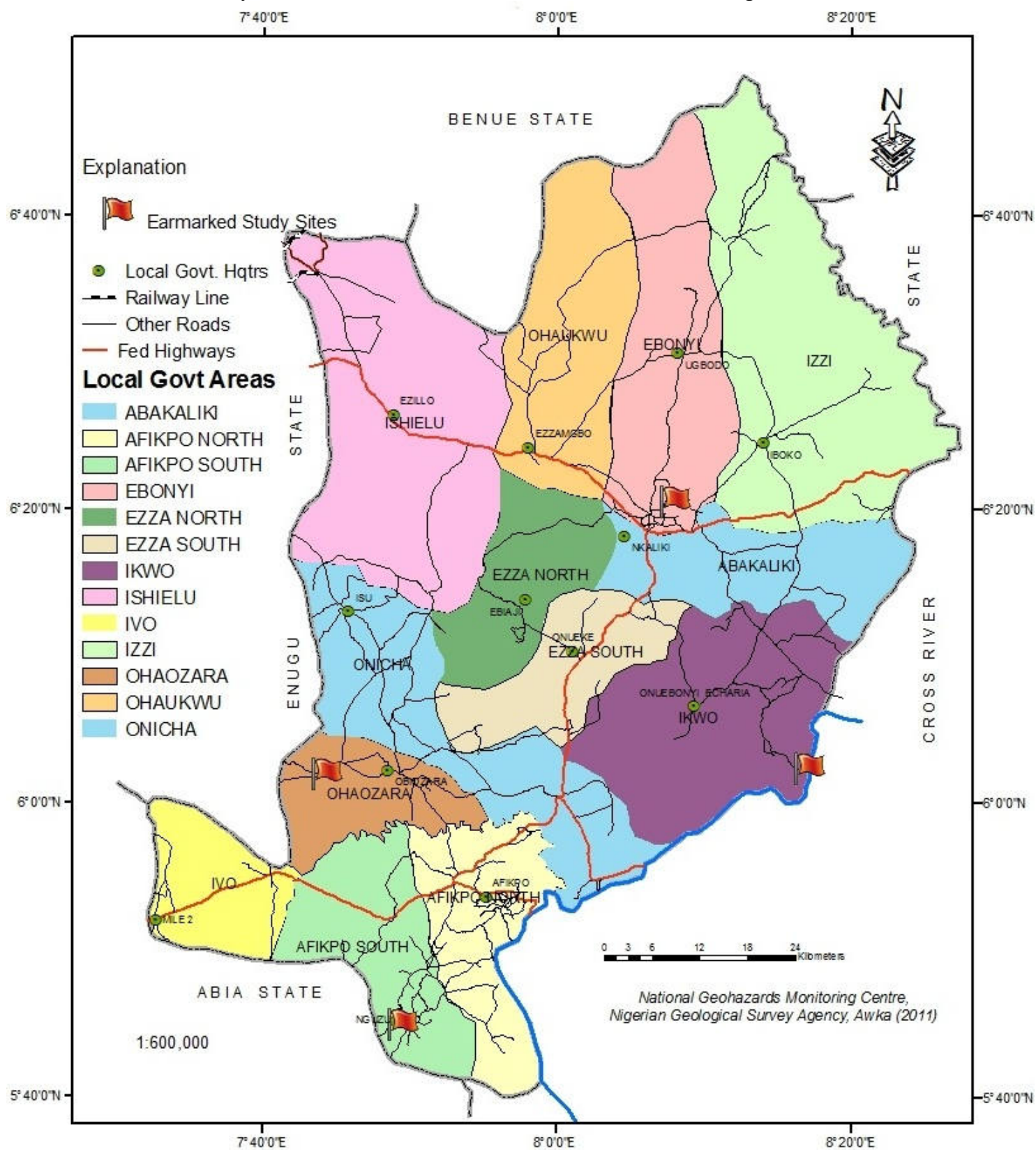

Figure 2: Administrative map of Ebonyi State (Source: National Geohazards, Awka)

\subsubsection{Climate and Vegetation}

The study area lies within the tropical rain forest belt of Nigeria and has two major climate regimes: the dry and the rainy seasons. The dry season lasts from November to April. It is characterized by intense scorching insolation and moderate relative humidity with temperatures between $29.5^{\circ} \mathrm{C}$ and $35^{\circ} \mathrm{C}$. November to February is the 
harmattan period during which dry north easterly winds decrease humidity, bring in dust and depress the average temperatures especially at night.

The rainy season, which starts in April and ends in is October, is characterized by high relative humidity and heavy precipitation in the form of large battering raindrops. The convectional nature of the heavy rainfall results in alternating periods of sunny and rainy conditions. July and September are usually the peak periods of the rains, usually separated by a short relatively dry spell called "August break". The average annual rainfall ranges of 2,284 $\mathrm{mm}$ (Iloeje, 1981).

The southeastern Nigeria lies within the climax vegetation of tropical rain forest which is now reduced to a sub climax secondary forest by human interference. Several hundred square kilometers have been replaced by palm tree plantations

\subsubsection{Geology}

Southeastern Nigeria lies within the Southern Benue Trough, Anambra and Niger Delta Basins. The states are underlain by the representative lithofacies of the three basins. The evolution of Benue Trough, Anambra and Niger Delta Basins are intricately related, though they differ in age and complexity. Benue Trough is thought to have originated as a part of the very extensive West and Central African Rift System (ARS) following weaknesses reactivated within the Pan-African Basement Complex during the break-up of the Gondwana Supercontinent, as supported by Plate Tectonic Theory (Grant, 1971). Chronologically, Anambra Basin originated following the tectonic depression of the area around the southern Benue Trough contemporaneous with the folding episode in the Santonian. On the other hand, the evolution of the Niger Delta Basin was due to the continued subsidence of the southern Benue Trough and Anambra Basins as defined by Chain and Charcot Fracture Zones.

The region is underlain by Late Cretaceous to Quaternary sediments of Southern Benue Trough, Anambra and Niger Delta Basins. The lithic fills include the followings: Albian Asu River Group, Coniacian Eze-Aku Group, Santonian Awgu Shale Formation, Campanian Nkporo Group, the Maastrichtian Coal Measures (Nsukka, Ajali and Mamu), Paleocene Imo Shale, Eocene Ameki Group and Miocene to Quaternary Ogwashi Asaba and Benin Formations. Igneous rocks outcrops are equally exposed south of Awgu, Afikpo and Abakaliki are evidence of volcanic activity in the Cretaceous times.

\subsubsection{Topography}

Hudson, 1981 observed that in simplest terms steep land is more vulnerable to water erosion than flat land for reasons that erosive forces, splash, scour and transport, all have greater effect on steep slopes. Gully erosion generally is a function of slope attributes. The slope length and the amount of soil erosion have always been proportional to the steepness of the slope. Also the slope geometry of hill sides (i.e. whether convex or concave) often contribute significantly to soil loss and gully development.

Topography of the southeastern region is characterized by steep slopes in cuesta areas. The region is traversed by two distinctive cuestiform topographies (i.e. Idah-Enugu-Okigwe-Arochukuwu and Awka-Orlu). The cuestiform lands attain heights of between $(170-500 \mathrm{~m})$ above sea level and act as driving force to gullying processes.

\subsection{Methodology}

The study approach involves three major stages:
A. Desk Study
B. Field Investigation
C. Data integration and analysis for derivation of geo-spatial information

\section{A. Desk Study}

This primarily includes:

* Literature review on all available geology, geomorphology, flood and erosion related materials in relation to Ebonyi State - Lower Benue Trough

* Geospatial data generation through the acquisition of high resolution Satellite imageries, remote sensing materials, available administrative map of the State and production of base maps (Igbokwe et al, 2006).

\section{B. Field Investigation}

The field investigations include:

* Ground truthing survey of the prioritized and other sites across the entire state 
* Non-spatial attribute dataset were generated for analysis

\section{Data Integration, Analysis and Derivation of geospatial Information}

Data processing was conducted through:

* Data correction, on digital and non-spatial attribute data

* Data Formatting, of digital and non-spatial attribute data

* Digital Image processing through image classification, image data integration and merging

* Biophysical modelling with the sole aim of deriving and generating geospatial information on gully erosion and flood hazards and resettlement action plan.

\subsection{Data Presentation and Discussion}

This section presents the data generated from the field work and the maps produced as follows:

Table 1: Table showing the Location by GPS and Geometry of the Gully and Flood Sites investigated in Ebonyi State.

\begin{tabular}{|c|c|c|c|c|c|c|c|c|c|c|}
\hline F1 & Name & Icon & Message & Latitude & Longitude & Alititude_ & Latitude_ & Longitude_ & Geomtc_sec & Attr_data \\
\hline 1 & NGUZU (LG.Hotr) & Crossed Square & Gully, Afikpo South LGA & $N 5^{2} 45.073^{\prime}$ & $E 7^{\prime} 49.510^{\prime}$ & 213 & 5.751217 & 7.825167 & Gully Head: Depth (D)metre \&Width (W)metre & 1325 \\
\hline 2 & NGUZU EDDA2 & Crossed Square & Gully, Afikpo South LGA & $N 5^{2} 44.650^{\prime}$ & $67^{\prime} 48.493^{\prime}$ & 142 & 5.74467 & 7808217 & Gully Head: Depth (D)metre \&Width (W)metre & 811 \\
\hline 3 & UHUNAGA FLOOD & Crossed Square & Flood, Ohaozara LGA & N6:1.997 & E7'44.234' & 52 & 6.033283 & 7.737233 & Flood site: Width (W) kilometre, Strgee (S)metre & 204 \\
\hline 4 & OHAISU WARDA & Crossed Square & Gully, Afikpo North LGA & NS553.480 & E7'55.904' & 106 & 5.891333 & 7.931733 & Gully Head: Depth (D)metre \&Width (W)metre & 303 \\
\hline 5 & FORUER HIGH CORT & Crossed Square & Gully, Afikpo North LGA & N5:553.764 & $E 756.349^{\prime}$ & 127 & 5.890067 & 7.93915 & Gully Head: Depth (D)metre \&Wioth (W)metre & 0 \\
\hline 6 & OGBAEB INGODO & Crossed Square & Flood (Narrow curvert, Afikpo Nort LGA & N5552.598 & $6757.929^{\prime}$ & 78 & 0 & 0 & Gully Head: Depth (D)metre \&Width (W)metre & $\overline{0}$ \\
\hline 7 & OVUMAAMANGBELLY & Crossed Square & curlvert overflow, Afikpo North LGA & N5553.337 & $E 756.454$ & 101 & 5.88895 & 7.9409 & Gully Head: Depth (D)metre \&Wioth (W)metre & 0 \\
\hline 8 & AMANKWWO & Crossed Square & Gully, Afikpo North LGA & N5'52.401' & E756.912 & 82 & 5.87335 & 7.948533 & Gully Head: Depth (D)metre \&Width (W)metre & 0 \\
\hline 9 & NGUZU-AIIII ROAD & Crossed Square & Gully, Afikpo South LGA & N5'46.1111 & E7'49.502 & 133 & 5.768517 & 7.825033 & Gully Head: Depth (D)metre \&Width (W)metre & 0 \\
\hline 10 & EKOLIOKAGWE & Crossed Square & Gully, Afikpo South LGA & $N 5^{\circ} 42.996^{\prime}$ & E7'48.849' & 157 & 5.7166 & 7.81415 & Gully Head: Depth (D)metre \&Width (W)metre & 0 \\
\hline 11 & EKOLI-OKAGWERD & Crossed Square & Gully, Afikpo South LGA & $N 5^{2} 44.762$ & E7'50.088' & 178 & 5.746033 & 7.8348 & Gully Head: Depth (D)metre \&Width (W)metre & 0 \\
\hline 12 & FEDERAL IIEDCCAL CENTRE & Crossed Square & Flood, Ebonyi LGA & N6" $19.9899^{\prime}$ & E8006.737 & 71 & 6.33315 & 8.112283 & & 0 \\
\hline 13 & ONU ENYII AGBAJA & Crossed Square & Flood(River bank), Izi LGA & N6'44.108' & E8'14.833' & 54 & 6.735133 & 8.24217 & & 0 \\
\hline 14 & EZZAIIGBO & Crossed Square & Stream bank, Ohaukwu LGA & N6'23.380 & $E 757.588$ & 112 & 6.389667 & 7.9598 & & 0 \\
\hline 15 & MIUDELE & Crossed Square & Flood, Ebonyi LGA & N6'19.303' & E8:07.207 & 65 & 6.321717 & 8.120117 & & 0 \\
\hline 16 & MIOKWU & Crossed Square & Flood \& Channza, Ebonyi LGA & N6"19.052 & E8006.621' & 63 & 6.317533 & 8.11035 & & 0 \\
\hline 17 & AMUSEMENT PARK & Crossed Square & Flood \& Channzo, Ebonyil LGA & N6" $18.990^{\circ}$ & E8:06.159' & 55 & 63165 & 8.10265 & & 0 \\
\hline 18 & TUHA HEAD BRIDGE & Crossed Square & Curlvert shoudder spill,Ohaukwu LGA & N6"28.677 & $E 757.552$ & 93 & 6.47795 & 7.9592 & & 0 \\
\hline 19 & UKWAGBANGBO & Crossed Square & Curlvert shoudder spill, Ohaukwu LGA & N6:29.981' & $E 757.448^{\circ}$ & 102 & 6.499683 & 7.957467 & & 0 \\
\hline 20 & UKWAGBA NGBO2 & Crossed Square & Curlvert shoudder spill, Ohaukwu LGA & N6:30.018 & $E 757.452$ & 107 & 6.5003 & 7.957533 & & 0 \\
\hline 21 & EFEREKPE & Crossed Square & Flood,bank of Cross River, "kwo LGA & N6:02.474' & E8'17.015' & 42 & 6.041233 & 8.283583 & & 0 \\
\hline 22 & NYYIIAGU KWNO & Crossed Square & Flood,bank of Cross River, kwo LGA & N6:03.317 & E8"14.653' & 45 & 60.055283 & 8.244217 & & 0 \\
\hline 23 & TECH SEC SCH NGUZU & Crossed Square & Gully Zone, Afikpo South LGA & $N 5^{2} 4.4 .961^{\prime}$ & E7'49.611' & 189 & 5.74935 & 7.82685 & & 0 \\
\hline 24 & UGWUAA & Crossed Square & Gully, Afikpo South LGA & N5'45.005' & E750.209 & 190 & 5.750083 & 7.835817 & & 0 \\
\hline 25 & EGBEBU CENTRAL SCHOOL & Crossed Square & Gully, Afikpo South LGA & $N 5^{2} 45.073^{\prime}$ & E7'50.656' & 212 & 5.751217 & 7.844267 & & 0 \\
\hline 26 & EGOELU EKOLLEDDA (Lands & 8 Crossed Square & Landsilide, Afikpo South LGA & N15'4.888 & $E 751.072$ & 188 & 5.748133 & 7.8512 & & 0 \\
\hline 27 & OGUHA EKOLLEDDA (Lands & Crossed Square & Landsilide, Afikpo South LGA & N5'45.828 & E751.109 & 217 & 5.7638 & 7.851817 & & 0 \\
\hline 28 & UKPOS & Crossed Square & Gully \& Flood(River bank), Onicha LGA & N6'02.395' & E7' $49.251^{\prime}$ & 54 & 6.039917 & 7.82085 & & 0 \\
\hline 29 & UNUBO & Crossed Square & Gully \& Flood Onicha LGA & N60.6.278 & E7'48.571' & 76 & 0 & 0 & & 0 \\
\hline 30 & ENUAQU & Crossed Square & Gully, Onicha LGA & N6:05.278 & E7'48.571' & 96 & 6.087967 & 7.805517 & & 0 \\
\hline 31 & OKPOSI NGBO & Crossed Square & GULLY & N16:32.916 & E8:00.443' & 143 & 5.766717 & 7.858283 & & 0 \\
\hline
\end{tabular}




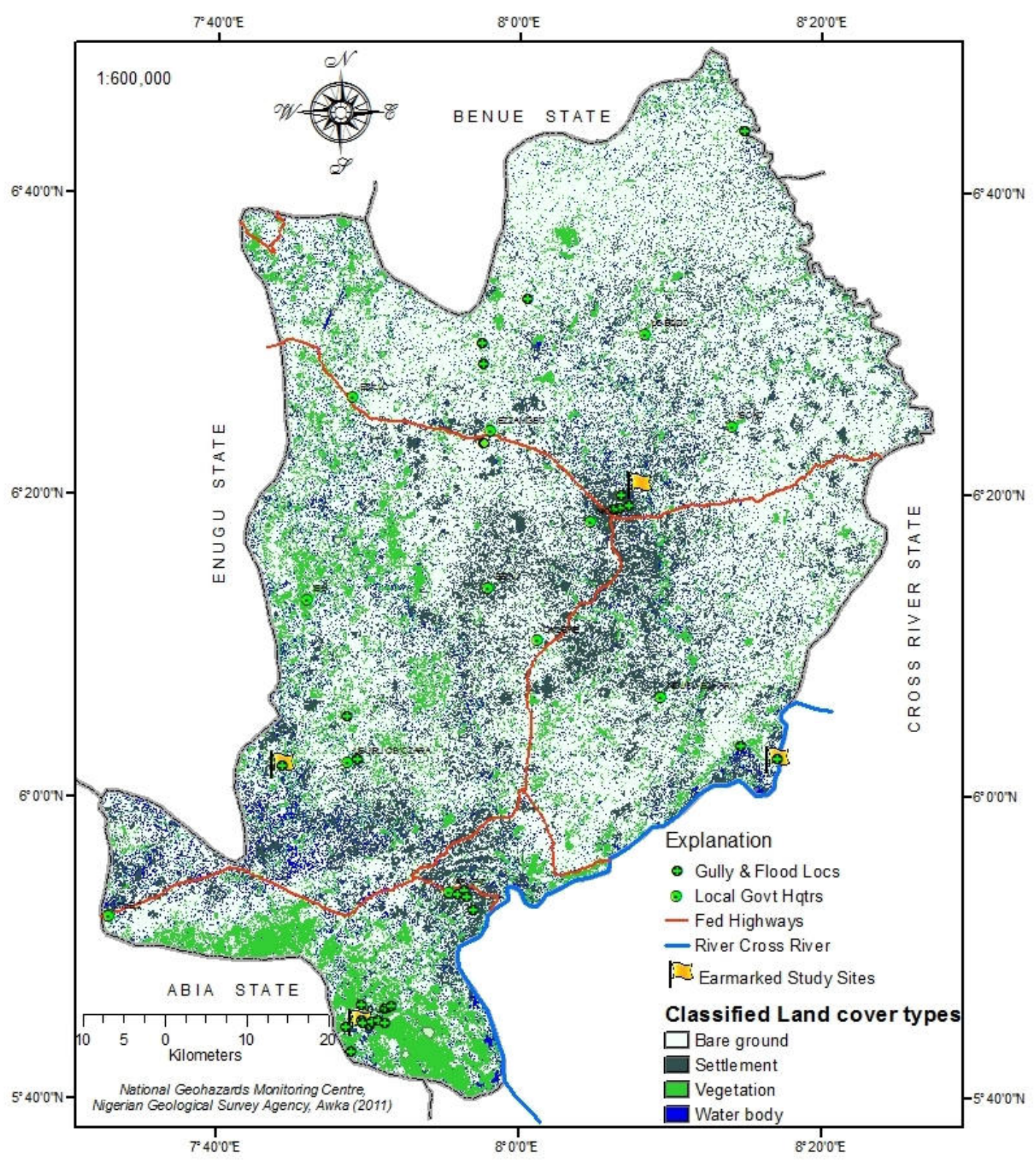

Figure 3: Classified Land cover map of Ebonyi State (Source: NGMC/NGSA, Awka, 2016) 


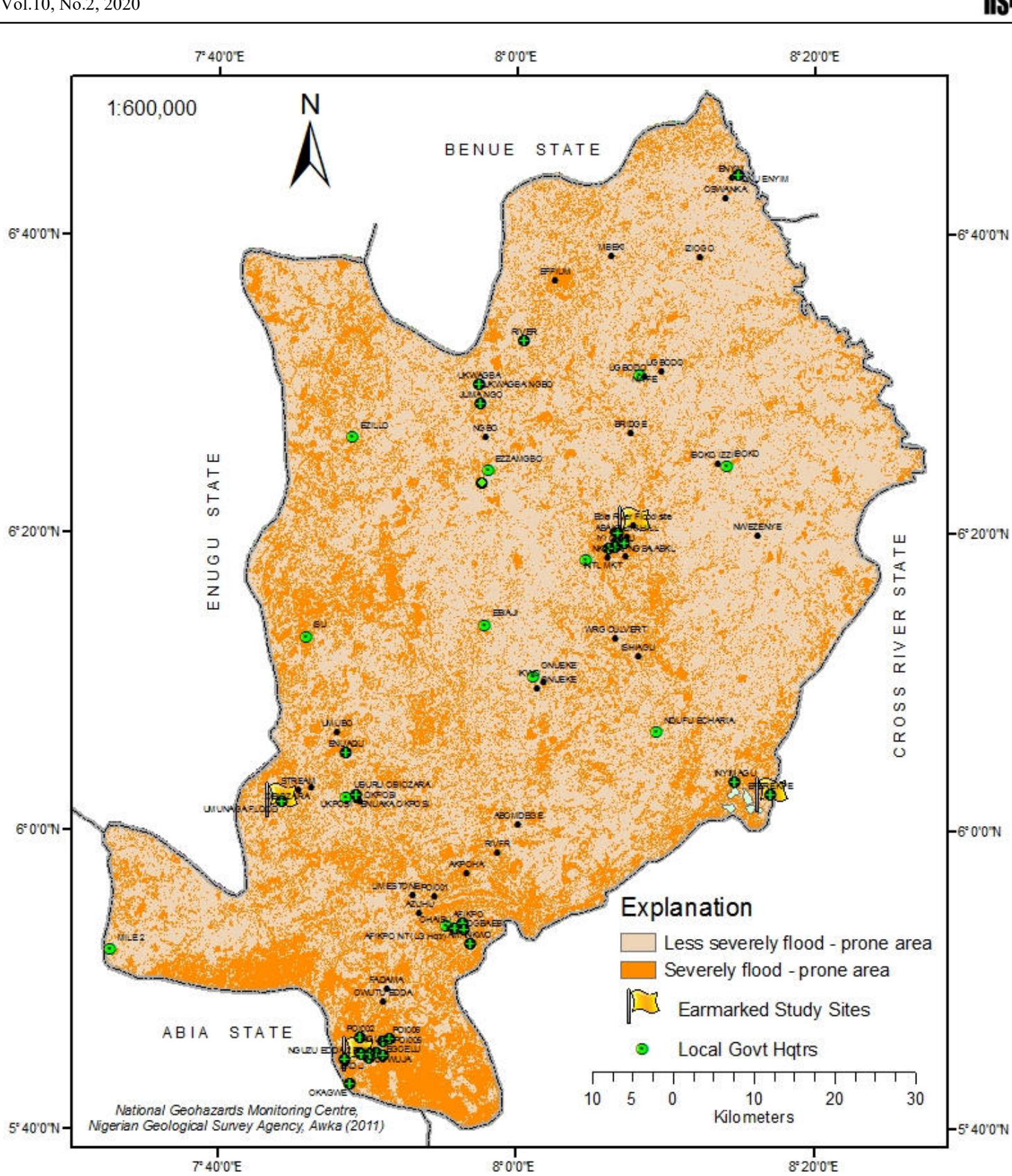

Figure 4: Flood severity map of Ebonyi State (Source: NGMC/NGSA, Awka, 2016)

Figures 3 and 4 shows the land use, land cover and flood severity maps of Ebonyi state. The two maps were produced using the SRTM (Shuttle Radar Topographic Mission), with resolution of 80meters. The principle of this software is that of using an aircraft with a sensor camera inbuilt, to capture the picture of the physical features of the earth. It gives information about the water bodies, elevation contour, digital terrain model, slopes and hillshades; which helps in determining flood and gully prone areas. The SRTM was imported into the ArcGIS platform and the section of Ebonyi state (study area) was cut out and subsequently the physical features present where extracted and identified.

The land use land cover map (figure 3) shows that there is greater percentage of bare land and vegetation in the North-eastern and South-western parts of the State respectively than settlement and water bodies. The flood severity map (figure 4) shows that the South-western part of the State (around Afikpo North and South, Ezza North and South) is more severely flood-prone than the North-eastern part. From these findings one will be able to plan 
for flood management and control within the state. Also considering the geology of the area the more severely flooded area is underlain by shale while the gully-prone areas are underlain mainly by Ajalli sandstone.

\subsection{Impacts of flood and gully erosion}

The impacts of flood and gully erosion as observed in Figures 3-7, includes the following:

- Soil and land loss (about $8 \%$ of total land mass) leading to shortage of land

- Destruction of houses and infrastructure

- Loss of economic crops and trees leading to low agricultural produces

- Population displacement and physiological trauma

- Threat to human lives and residential houses
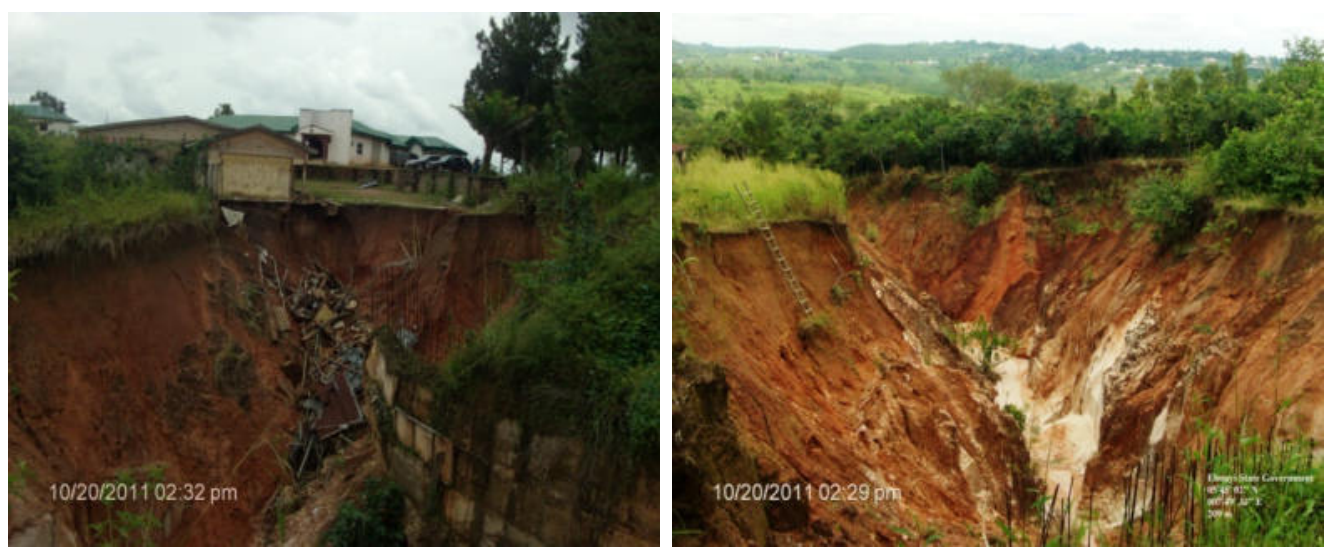

Figure 5: Court house destroyed by gully erosion at Afikpo South LGA

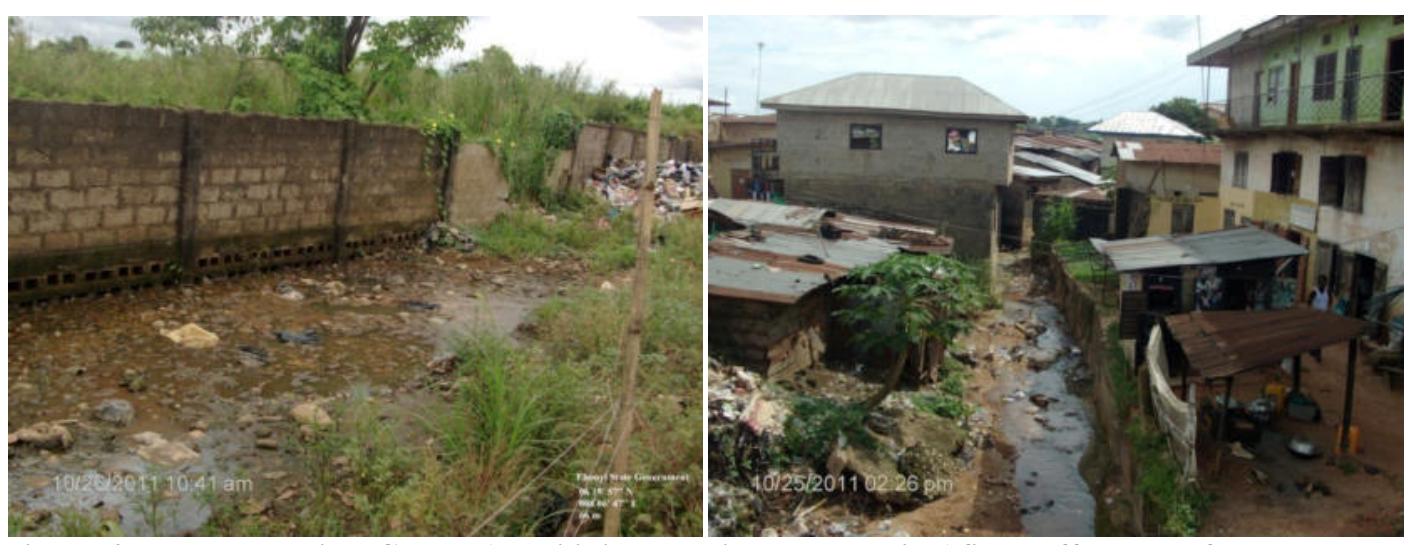

Figure 6: Federal Medical Centre Abakiliki and residence areas in Afikpo affected by flood 

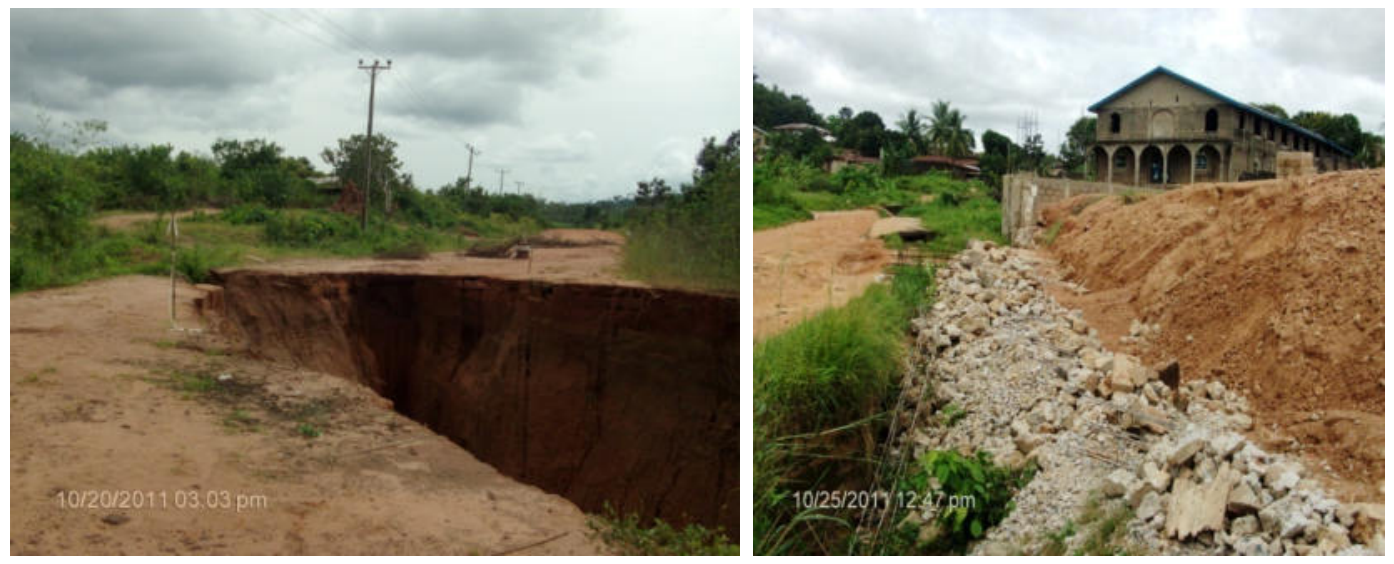

Figure 7: Electric poles and wires under threat by gully erosion at Nguzu Edda and catholic Church fence destroyed by flood water

\subsection{Recommendations}

1. At the individual level, runoff within compounds should be controlled by harvesting rain water and by channeling floods into deep wells or sumps.

2. In gully-flood prone areas, each community should protect their roads by using sumps and catch pits and enforcing the rules prohibiting releasing of floods out of walled premises.

3. The various tiers of government should enact and enforce laws aimed at general environmental conservation, including land and soil protection in susceptible areas.

4. It is also the duty of governments at various levels to organize enlightenment campaigns regarding nature conservation in general and gully prevention in particular.

5. Professional and expert study of terrains prior to designs and construction of erosion control works should be seriously done.

6. The three tiers of government should specifically prohibit farming, buildings, construction of roads near and habitation on slopes and breaks of slope. Also periodic maintenance of existing civil works on ground should be ensured.

7. Finally, adequate disposal of refuse waste should be enforced to allow easy passage of flood water along waterways.

\section{References}

Allen, P.A., (1997). Earth Surface Process. Blackwell science Ltd, Oxford, 404p.

Angrist, S.W. and Hepler, L.G., (1967). Order and Chaos: Laws of Energy and Entropy. Basic Books Inc. Middlesex, $210 \mathrm{p}$.

Grant, N.K., (1971). South Atlantic, Benue Trough and Gulf of Guinea Cretaceous triple junction. Bull. Geo. Soc. Am., v. 82, p $2295-2298$

Hudson, N. W., (1981). Soil Conservation. Batsford, London.

Igbokwe, J. I., Akinde, J. O., Dang, B. A., Alaga, T., Ono, M. N., Nnodu, V. C., and Anike, L. O., (2008). Mapping and monitoring of impact of gully erosion in South-eastern Nigeria with satellite remote sensing and geographic information system. The International Archives of Photogramentry, Remote Sensing and Spatial Information Sciences v.37, Part 38. Beijing 2008, p 865-870.

Iloeje, N. P. (1981): A New Geography of Nigeria (Revised Edition), Longman Nig. Enugu. P. 37.

Posen, J.W.A., Torri, D.B., and Vanwalleghem, T., (2011). Gully erosion: Procedures to adopt when modeling soil erosion in landscapes affected by gullying, In Morgan, R.. P. C. and Nearing, M. A.(Editors) Handbook of Erosion Modeling John Wiley \& Sons Ltd, Sussex, p. 360-380. 